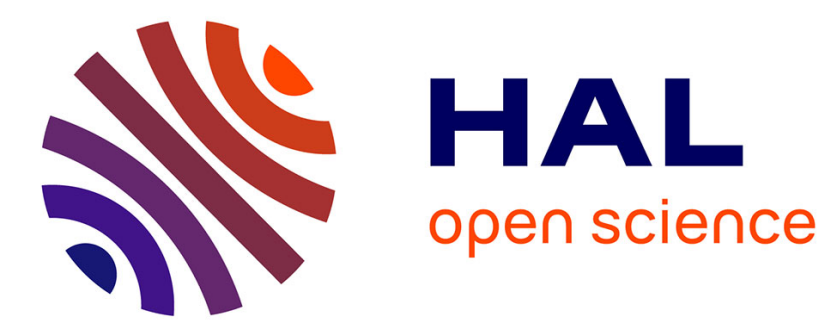

\title{
Capacity Investment under Demand Uncertainty. An Empirical Study of the US Cement Industry, 1994-2006
}

\author{
Jean-Pierre Ponssard, Catherine Thomas
}

\section{To cite this version:}

Jean-Pierre Ponssard, Catherine Thomas. Capacity Investment under Demand Uncertainty. An Empirical Study of the US Cement Industry, 1994-2006. 2010. hal-00511563

\section{HAL Id: hal-00511563 \\ https://hal.science/hal-00511563}

Preprint submitted on 30 Aug 2010

HAL is a multi-disciplinary open access archive for the deposit and dissemination of scientific research documents, whether they are published or not. The documents may come from teaching and research institutions in France or abroad, or from public or private research centers.
L'archive ouverte pluridisciplinaire HAL, est destinée au dépôt et à la diffusion de documents scientifiques de niveau recherche, publiés ou non, émanant des établissements d'enseignement et de recherche français ou étrangers, des laboratoires publics ou privés. 


\section{ECOLE POLYTECHNIQUE}

CENTRE NATIONAL DE LA RECHERCHE SCIENTIFIQUE

CAPACITY INVESTMENT UNDER DEMAND UNCERTAINTY. AN EMPIRICAL STUDY OF THE US CEMENT INDUSTRY, 1994-2006*

Jean-Pierre PONSSARD

Catherine THOMAS

Cahier $n^{\circ} \quad 2010-20$

\section{DEPARTEMENT D'ECONOMIE}

Route de Saclay

91128 PALAISEAU CEDEX

(33) 169333033

http://www.economie.polytechnique.edu/

mailto:chantal.poujouly@polytechnique.edu 


\title{
Capacity Investment under Demand Uncertainty. An Empirical Study of the US Cement Industry, 1994-2006*
}

\author{
Jean-Pierre Ponssard and Catherine Thomast
}

August 24, 2010

\begin{abstract}
Uncertainty about the level of demand is thought to influence irreversible capacity decisions. This paper examines some implications of the theory literature on this topic in an empirical study of the US cement industry between 1994 and 2006. Firms in this sector have the ability to deliver cement either from domestic plants or from imports. Since cement is costly to transport via land, the difference in marginal cost between local production and imports varies across local markets. The marginal cost of imports is lower in areas with access to a sea port, decreasing the relative value of investing in local capacity sufficient to supply positive local demand shocks. In the presence of uncertain demand, firms may choose to serve these markets via both domestic production and imports. Consistent with the theory, we find a negative relationship between the average level of excess capacity and demand volatility only for coastal areas. An increase in demand volatility is associated with an increase in excess capacity only in landlocked areas. More generally, the paper shows that the cost of imports relative to the cost of domestic production affects the relationship between uncertainty and domestic capacity decisions. The results suggest that a unilateral climate policy in the US may induce a partial international relocation of capacity in carbon intensive industries, such as cement, by increasing the relative cost of domestic production.
\end{abstract}

Keywords: Capacity Investment, Demand Uncertainty, Imports, Cement. JEL Classifications: D24, D81, F18, L61.

* We would like to thank Amit Khandelwal, Bruce Kogut, Benjamin Lockwood, Guy Meunier, Dmitri Nizovtsev, Hendrik G. van Oss, and attendees at the 2010 International Industrial Organization Conference and the 2010 Academy of Management for helpful comments. Benjamin Lockwood also provided excellent research assistance. Jean-Pierre Ponssard's research on this project has been partly supported by the École Polytechnique Chair for Business Economics. All errors are our own. tÉcole Polytechnique and Columbia Business School.

Email: Jean-Pierre.Ponssard@polytechnique.edu and cmt2122@columbia.edu. 


\section{Introduction}

Several important theory papers investigate the relationship between the optimal level of capacity and demand uncertainty. Ordinarily the relationship is ambiguous. We study this relationship in the context of the US cement industry where firms may have access to two technologies: capital-intensive local production at a low marginal cost, and a flexible technology corresponding to importing at a higher marginal cost that includes transport costs. The research question can be summarized as follows: Does variation in access to imports help explain variation in the relationship between local demand uncertainty and the domestic capacity decisions made by cement producers in the US?

We show that there is a negative relationship between the level of excess cement production capacity and demand volatility in coastal regions in the US between 1994 and 2006, where the incremental marginal cost associated with importing cement is lower. In landlocked regions where the relative cost difference is greater, increases in demand volatility are associated with increases in excess capacity. The average plant size is also increasing with demand volatility within landlocked regions but not within coastal regions.

There are four major reasons why the US cement industry is an attractive industry in which to study the role of uncertainty in investment decisions. First, the industry is regionally segmented, and there are many plants located throughout the country in varying economic environments. Second, capacity decisions are the major firm-level decision in the industry since cement production is capital intensive. Third, demand for cement in each regional market is largely uncertain. It follows the general business cycle as well as the local cycles typical of the construction industry. Last, in recent decades, long-haul maritime imports have played an increasing role in absorbing fluctuations in US domestic demand. Importantly, a large fraction of the installed base of US cement capacity is controlled by the large multinational firms that dominate this industry worldwide. Following Kogut and Kulatilaka (1994) these firms may use their global production networks to adapt to the demand fluctuations in a given market.

The theoretical framework analyzing capacity decisions under this type of uncertainty goes back to the Rothschild and Stiglitz papers $(1970,1971)$. These authors investigate the monotonicity properties of an irreversible decision when risk increases. They provide a necessary and sufficient condition for such a property to hold, point out that this will rarely be the case, and indeed provide a number of economic examples in which it does not. This work can be related to the option value literature originating with Henry (1974), Arrow and Fisher (1974), and fully developed by Dixit and Pindyck (1992). There the question concerns the impact of a future learning phase on the current irreversible decision. As has been widely noted, the relationship between uncertainty in general and investment is theoretically ambiguous. 
Our empirical analysis relies on an analytical model tailored to the cement industry developed by Meunier and Ponssard (2009). In a setting of oligopolistic competition in a local market, each firm has to decide its capacity when facing uncertain demand. Once the level of demand in a given time period is revealed, the firm may use imports to complement domestic production if local capacity is saturated. The optimal capacity choice is monotonic with respect to the level of uncertainty, contingent on the cost of imports relative to the domestic production cost. Specifically, capacity is increasing with uncertainty if the cost of imports is relatively large, and decreasing if the cost of imports is relatively small. This contingent property is at the crux of our empirical analysis.

There are a number of papers which relate directly or indirectly to our work. The closest paper is Rob and Vettas (2003). In their model, as in ours, FDI and exports (domestic production and imports, respectively, in our model) will co-exist under some circumstances. Much of the prior existing theory on FDI offers only limited explanation of this empirical regularity, as noted by Blonigen (2001) and Head and Ries (2001). However, Rob and Vettas focus on the optimal strategy mix between FDI and exports as demand grows over time, while we focus on the optimal strategy mix (between domestic production and imports) as demand uncertainty varies across settings with differing variable costs of imports.

A number of theory papers have studied the impact of uncertainty on capacity decisions. Firms are predicted to select a higher capacity with uncertainty (Gabszewicz and Poddar, 1997). Demers (1991) analyzes capacity choice in a dynamic oligopolistic Markov model. The author shows that the equilibrium capacity is also increasing with uncertainty. In this model the firm is constrained to always produce as much as its earlier capacity commitment, possibly more with a penalty cost, but never less. These theory models assume only one technology, and can hence be viewed as analogous to the conditions in landlocked markets in our analysis, where the import technology is prohibitively costly. We allow firms access to two technologies - domestic production and imports - in coastal markets. This two-technology setting generates the contrasting predictions in different geographic markets which we explore in the data.

Capacity decisions may also be analyzed as a strategic entry barrier. Typically, a monopoly or an oligopoly may operate with excess capacity to deter entry. There have been many theoretical contributions that justify such strategic behavior, such as Spence (1977) and Dixit (1980). A number of empirical studies have tested this hypothesis in specific industry studies, see for instance Ghemawat (1984) and Mathis and Koscianski (1997). As noted by Lieberman (1987), the empirical results have in general failed to provide strong supporting evidence. Our focus in this paper is on the role played by uncertainty in capacity decisions, and we attempt to control for incentives to engage in preemptive behavior by controlling for local demand growth in the empirical work.

To sum up, we rely on a model of capacity decisions designed for the cement industry. This model exhibits original monotonicity properties between capacity and uncertainty 
which vary depending on the relative cost of a second production technology. Empirical evidence from the US cement industry supports the model's predictions.

The significance of our empirical contribution comes from the observation that, whereas the relationship between uncertainty and investment is a major focus of macroeconomic study, there is a limited amount of work at the micro level. Carruth, Dickerson and Henley (2000) survey the existing empirical work. Studies of plant or firmlevel variation in investment and uncertainty, including Leahy and Whited (1996) and Guiso and Pirigi (1999), focus on roles played by cross-industry variation in investment irreversibility and also, to a lesser extent, on differences in market structure. Bloom et al. (2007) evaluate the predictions of a dynamic model about how uncertainty affects the responsiveness of investment to shocks to demand using firm-level data from the UK. Goldberg (1993) finds a negative relationship between investment and exchange rate variability in some sectors, but Campa and Goldberg (1995) find that exchange rate variability has no significant effect on investment levels in US manufacturing. There are even fewer industry-level studies. Notable exceptions include the studies of the North Sea oil by Hurn and Wright (1994) and Favero et al. (1994). Bell and Campa (1997) find no relationship between product demand volatility at the country level and capacity investment in the chemical processing industry. Most micro-level empirical work is based on variation in the option value of delaying investment, dynamics and adjustment processes. Our approach is closer to the original perspective taken in Rothschild and Stiglitz in that we are interested in the impact of the level of demand volatility on irreversible decisions.

The Meunier and Ponssard model was originally devised to investigate the "leakage" issue in the cement industry. A high unilateral carbon price increases the domestic cost of production relative to foreign imports, hence production and $\mathrm{CO} 2$ emissions may simply "leak" to other countries rather than decline overall. The model predicts that the implementation of a unilateral climate policy may have a negative long term impact on local investment levels, amplifying the short term competitiveness impact usually captured in static models. Our empirical findings provide an indirect way to test this prediction. In this study, landlocked districts are analogous to domestic countries prior to the imposition of a unilateral carbon price, and coastal districts reflect the ex-post case. Based on this analogy, our findings suggest that there is indeed a relocation effect of capacity due to a high domestic carbon price. We return to this point in the concluding section.

The paper is organized as follows: Section 2 provides some background on the cement industry and describes the data used in the study. The analytical model that sustains our empirical testing is described in Section 3. Section 4 develops the methodology employed and Section 5 describes the empirical results. General implications of these results are addressed in the concluding section. 


\section{The cement industry}

\section{General characteristics of the cement industry}

There are a limited number of competitors in any one geographical location in this industry. As described in D'Aspremont et al. (2000), demand for cement is more or less proportional to the density of the population. Production takes place in large plants and, once built, the capacity of a given plant cannot be increased without large reinvestment. In addition, markets are horizontally differentiated. Quality-wise cement is a homogenous good, but a high transportation cost relative to the production cost creates strong spatial differentiation.

Local demand tends to be quite volatile, generating significant regional differences between supply and demand. These differences need to be balanced with inter-regional flows, some from adjacent regions, others, in particular if the region is on the coast, through long haul flows. ${ }^{1}$ The conditions for long haul transportation of cement changed drastically in the late seventies (Dumez and Jeunemaitre, 2000). Because of technological change, it became possible to transport cement in bulk quantities safely and cheaply in very large ocean-going vessels, which, however, remain too large to pass through the US river system. This triggered a major change for the US cement industry. The import of cement to areas such as Florida, California, New York, and Texas increased steadily, coming from South America, Europe, or Asian countries. It was also at this time that the world cement industry entered a phase of ownership concentration, indirectly driven by this enlargement of its strategic market. In 2007, as stated by analysts' reports, the top five cement firms accounted for approximately $20 \%$ total world market share. The world cement industry may be seen as a network of regional oligopolies, Ghemawat and Thomas (2008).

Major cement firms such as Cemex, Holcim and Lafarge typically operate a large number of plants. ${ }^{2}$ The existence of such networks allows these firms to optimize their sourcing of production at any point in time depending on local supply and demand conditions. ${ }^{3}$ Their short term optimization depends on their available capacities in the various markets and on the relative production and freight costs. As such they have a

\footnotetext{
${ }^{1}$ While possible to stock limited quantities of clinker from month to month, particularly during the winter when cold temperatures may prohibit construction activity, producers do not stock finished cement from year to year. From 2002 to 2006 district-level cement stocks at year-end relative to annual production remained at around 7 to $8 \%$, in high and low demand years.

${ }^{2}$ According to their 2009 websites, Cemex operates in 79 plants (in 50 countries), Holcim 151 plants (in 70 countries, and Lafarge 166 plants (in 79 countries).

${ }^{3}$ It is quite difficult to obtain quantitative data on this subject. Multinationals use subsidiaries to make these long haul flows. The actual market share of the global players differs across countries, along with their involvement in the import/export flows. Multinationals' market share is typically higher in developed economies such as the US or in Europe than in emerging countries such as China or South America. Our framework is designed for countries where multinationals dominate production. See Salvo (2010) for a discussion of the role of imports on domestic competition in Brazil.
} 
competitive edge over smaller firms that are limited to a given regional market. Traders may also be active to complement the lack of local capacities. These traders may indeed react quickly to an occasional disequilibrium but they do not have the long term efficiency to sustain long haul trade flows. They often prefer to sell the market positions obtained at peak demand to local players when the downturn comes.

\section{The US cement industry}

We now turn to the data on the US cement market used in this study, noting that demand fluctuates at the local level within the US. Our primary data is published by the U.S. Geological Survey (USGS) and summarized in the annual Minerals Yearbook. ${ }^{4}$ In the data, the US is divided up into 23 regional districts, the boundaries and groupings of which differ slightly across years. We construct time series data by district for cement capacity, production, and demand, grouping together districts where necessary. ${ }^{5}$ The data are summarized in Table 1 and pairwise correlation coefficients for the key variables used in the study are given in Table 2.

\section{(Excerpt from) Table 1: a classification of US cement markets}

\section{District Name}

Alabama

Alaska, Hawaii, Oregon, Washington

Arizona, New Mexico

Arkansas, Oklahoma

Landlocked Indicator

California, Northern

California, Southern

Colorado, Wyoming

Florida

Georgia, Virginia, West Virginia, South Carolina, Maryland

Idaho, Montana, Nevada, Utah

Illinois

Indiana

Iowa, Nebraska, South Dakota

Kansas

Kentucky, Mississippi, Tennessee

Michigan, Wisconsin

Missouri

New York, Maine

Ohio

Pennsylvania, Eastern

Pennsylvania, Western

Texas, Northern

Texas, Southern

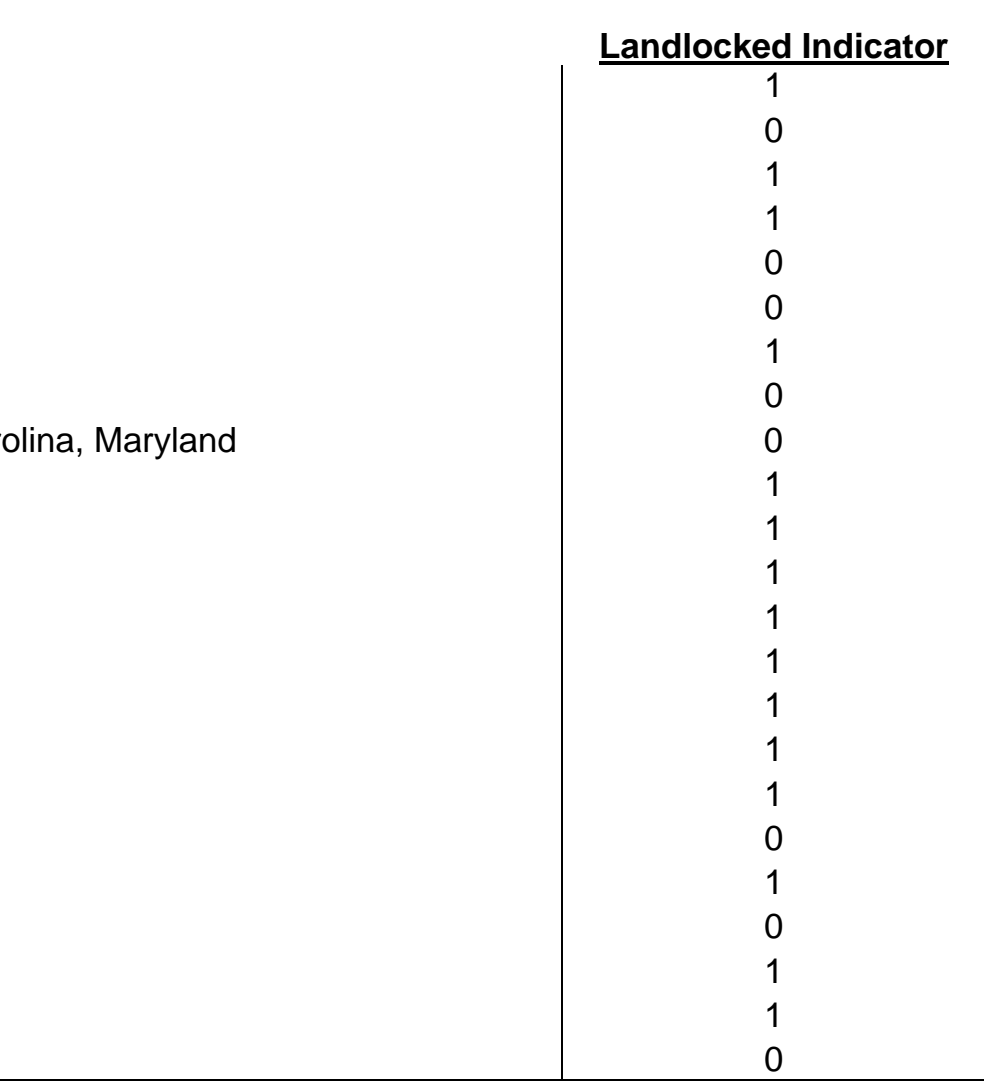

\footnotetext{
${ }^{4}$ We are grateful to Hendrik G. van Oss for advice on interpreting this data.

${ }^{5}$ The district containing Alaska, Hawaii, Oregon, and Washington, the district containing Georgia, Virginia, West Virginia, South Carolina, Maryland, and the district containing Michigan and Wisconsin, sometimes appear in the minerals yearbook broken up into different groupings.
} 
The USGS breaks down total imports of cement and clinker by customs district. Major import terminals include Tampa, FL, New Orleans, LA, Los Angeles, CA, Miami, FL, and Houston-Galveston, TX. Smaller import terminals are spread out over the East Coast of the US and include Baltimore, MD, New York City, NY, Norfolk VA, and Philadelphia, PA. ${ }^{6}$ In each year, there are also imports to Detroit, $\mathrm{Ml}$ and other northern Midwestern districts from Canada. All of our results are robust to classifying both the Michigan and Wisconsin district and the Ohio district as coastal rather than landlocked, reflecting their accessibility via lake transport from Canada. ${ }^{7}$

Our study employs data from 1994 to 2006. Since the lifespan of a cement plant may exceed 40 years, it is important to study a relatively long time period to understand capacity decisions. Graph 1 presents the evolution of cement consumption and imports between 1980 and 2006.

Graph 1: Demand and imports in the US cement market, 1980-2006.

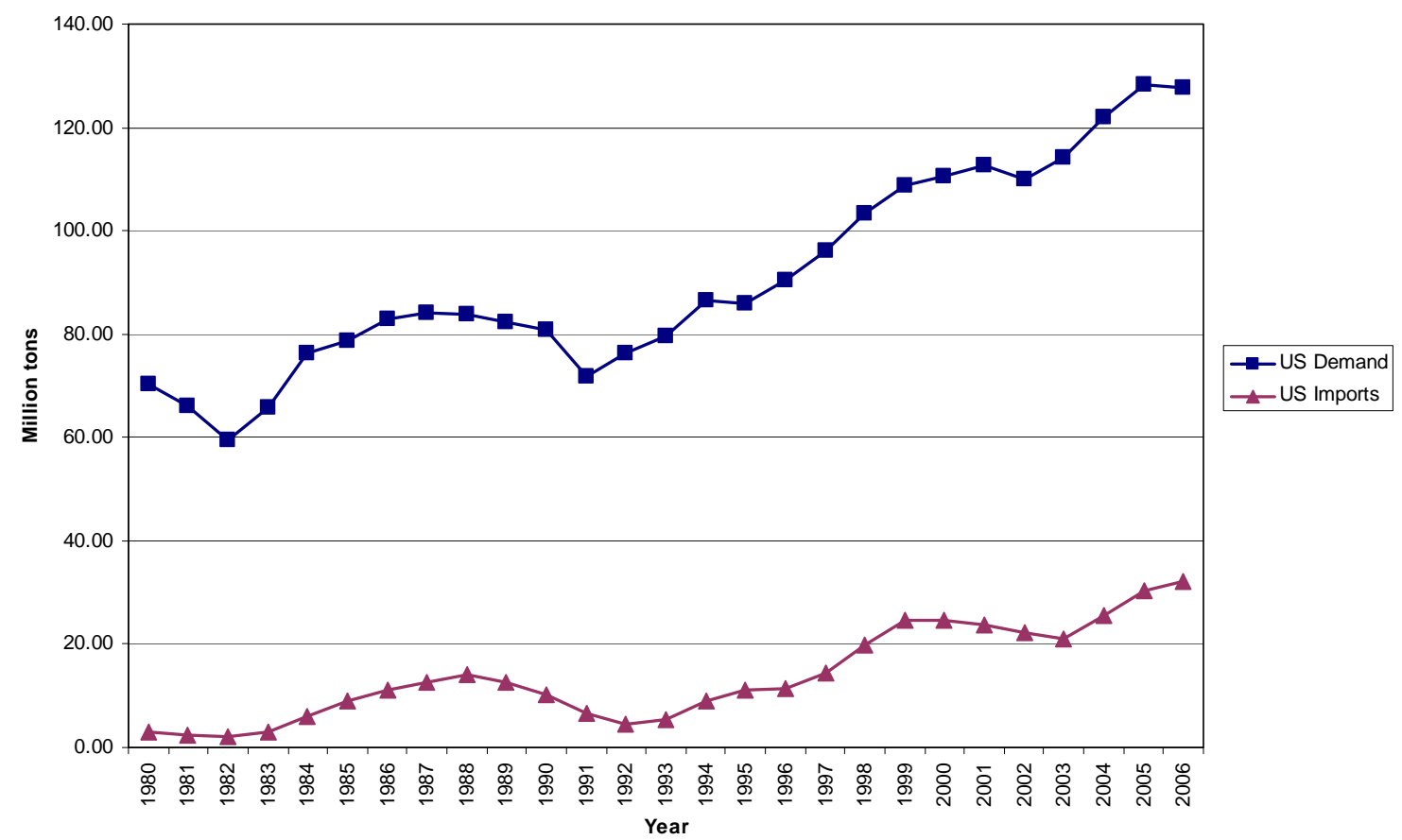

Over the first part of this time period, up to the early 1990s, the cement industry was considered a mature business (for a discussion on the US cement industry at that time, see Scherer's postface in Dumez and Jeunemaitre, 2000). A large fraction of the US

\footnotetext{
${ }^{6}$ This list is not comprehensive. Annual statistics can be found in Table 18 of the Cement Yearbook.

${ }^{7}$ Alabama has limited imports from the terminal at Mobile, although the largest cities in this district are located relatively far inland. Arizona imports cement from Mexico at Nogales, an inland border crossing. Nonetheless, all our results are robust to classifying both or each of these districts as coastal rather than landlocked. These results and the results from other alternative district classifications are available from the authors on request.
} 
industry was acquired by European (and Mexican) companies (this acquisition wave is discussed in Collomb and Ponssard, 1984). It is also at the beginning of this period that technical change made long haul imports feasible and relatively cheap. By the early 1990s, the US cement industry had been partly restructured and imports came in to the country largely via the new domestic players. ${ }^{8}$ In the early 2000s, according to industry sources, global cement players such as Cemex, Holcim, Lafarge, and Lehigh (Heidelberger) operated import terminals located in the East coast. We may certainly hypothesize that the proposed adjustment process of domestic capacities to cope with demand fluctuations had taken place.

One further point is worth attention. Imports are indeed positively correlated with aggregate domestic consumption. The regression coefficient capturing this correlation (the "beta" of a regression of the percentage deviation from the mean level of imports on the equivalent for domestic demand) is computed to be 2.55 , which demonstrates that imports are correlated with domestic consumption and tend to be more volatile.

District-level capacity is measured in our data as the finish grinding capacity in thousand metric tons, and is based on the grinding capacity required to produce a plant's normal output mix, including both portland and masonry cement, allowing for downtime for routine maintenance. Production, also in thousand metric tons, includes cement produced using imported clinker. The USGS Minerals Yearbook also includes data on the number of active plants by district - which allows us to measure average plant size in each year - and the percentage of plants that are dry and wet process. ${ }^{9}$ Table 1 summarizes the levels of capacity investment in each district in 1994 and 2006. There was an increase of $26 \%$ in the total metric tonnage of cement capacity in the US over this time period. The total number of plants declined by 5 to 113 in 2006, meaning that the average plant size increased by $31 \%$. There was also a $15 \%$ increase in the percentage of plants that used the relatively efficient dry or both wet and dry process rather than wet process technology.

These aggregate measures mask substantial variation across districts. The standard deviation of the percentage change in capacity is $29 \%$. Three districts - Ohio, and Eastern and Western Pennsylvania - saw declines in capacity. Northern Texas and the district containing Georgia, Virginia, West Virginia, South Carolina, and Maryland saw the largest absolute increases in capacity. The percentage increases were largest in

\footnotetext{
${ }^{8}$ At different times over the course of the period studied here, various importers were subject to antidumping charges brought against them by the US government and antidumping duties were subsequently imposed. While this may have affected the relative cost of imports overall, the relative price difference between local production and imports remained much greater for landlocked than for coastal districts.

${ }^{9}$ The statistics for the percentage of plants that are dry or wet process come from Table 5 of the USGS annual yearbook each year which details the technology in clinker plants only. The data on the total number of plants in each district used in the study are taken from Table 3 each year which details all white cement plants by district.
} 
Kansas, the district containing Kentucky, Mississippi, and Tennessee, Northern Texas, and Florida, at $85 \%, 74 \%, 68 \%$, and $67 \%$, respectively. The largest increases in average plant size took place in the Colorado and Wyoming district, which also saw a plant closure. Other large increases were seen in Kansas and Northern Texas. There were no decreases in average plant size in any district. 7 of the 23 districts had $100 \%$ dry or both wet and dry process plants in 1994, 10 of the remaining 16 districts saw an increase in the percentage of dry process plants, and 2 districts saw a decline. ${ }^{10}$

The demand data is aggregated by the USGS up from the state-level cement shipments to final customer. It includes cement produced from imported clinker and imported cement shipped by domestic producers and importers. Table 1, panel A, also summarizes the demand data by district in 1994 and 2006. Much of the variation in capacity across districts corresponds with variation in regional economic growth, and so to seek to understand the roles played by demand volatility we must also control for the role of demand growth in explaining these patterns. We measure demand growth as the average percentage change in the level of demand over the prior four years.

To measure demand uncertainty for each district, we construct a measure of the variance in demand levels over the past four years and the current year. To avoid overstating uncertainty we de-trend the data to account for changes in demand levels that are consistent with patterns that are arguably predictable. Since this measure of variation will be a function of the level of demand, we also normalize our uncertainty measure to facilitate comparison of uncertainty across districts of different sizes. To do this, we regress demand by district over the past five years on a constant and take the standard deviation of the five residual values, divided by the mean demand level over the five years. Panel B of Table 1 lists the district level mean demand growth and demand volatility over the data period.

We note that our measure of volatility is backwards-looking since it is constructed using district-level data from the last four years. Any increase in volatility is due to the level of demand in the current year being less similar to the level of demand for the past three years than is the level of demand four years ago to the prior three years. As will be described in Section 4, we also classify districts into high and low demand volatility districts, capturing whether the level of volatility is higher or lower than the mean level across districts over the entire time period. ${ }^{11}$

\footnotetext{
${ }^{10}$ While regulation may play a role in capacity decisions, it is more likely to act as a very local constraint and unlikely to matter differently in landlocked and coastal districts. ,

${ }^{11}$ Carruth et al. (2000) contain a discussion about the relative merits of different measures of uncertainty. Guiso and Pirigi (1999) is one of very few studies that uses survey data on manager's certainty about future demand as a measure of firm-level uncertainty.
} 


\section{The analytical model applied to the US data}

As mentioned in the introduction, our empirical analysis is based on the model developed by Ponssard and Meunier (2009). The model features a local oligopoly that faces demand fluctuations. It was designed to study the impact of the EU-ETS on investments in the EU cement industry. In this section, we describe its application to the present context, and discuss its key predictions.

Each firm may source its production from plants in two areas, some located in the "home" market and some located abroad, i.e. "foreign" plants from which it may import. Home plants have a lower variable cost and are capacity constrained. Foreign plants have a higher variable cost, when including the cost of transport to the home market, and are not capacity constrained because there are many of them that can potentially export to this home market.

Our focus is on the dependence of the capacity decisions at home on import costs as demand uncertainty increases. Imports will be required at peak demand levels, given the home capacity constraint. Consequently, the optimal capacity depends on the relative cost of import costs versus domestic production costs. Intuitively, the lower the import cost the more beneficial it is to import and the lower the optimal capacity should be. This intuition can be related to the original paper by Rothschild and Stiglitz (1971) (example $D$ in Section 2) in which a rigid input (capital) may be combined with a flexible one (labor). There, the choice of capacity depends on the relative elasticity of substitution between the two inputs.

In our application to the cement industry, the market is the US district. In each district there are local plants. These local markets differ according to the cost of importing cement. It will be assumed that these costs are higher in landlocked districts (i.e. with no access to the ocean) than in coastal ones (i.e. with access to the ocean). In practice, the import costs are subject to a number of other factors such as the price of oil, or the overall macroeconomic conditions. However, it will remain true at all times that it is more expensive to import into a landlocked district than into a coastal one. We implicitly assume that adjacent markets follow similar business cycles so the balance of supply and demand mostly comes from long haul flows, or from a ripple effect. ${ }^{12}$ This appears to be borne out in the data. The mean district pairwise correlation in deviations from mean excess capacity between 1994 and 2006 is positive, and the mean pairwise correlation for geographically proximate districts tends to be more strongly positively correlated. $^{13}$

\footnotetext{
${ }^{12}$ This explains why in the model firms do not export from their domestic production capacity. As for exporting towards foreign markets, we note that US exports remain a very low percentage of US annual production - at around 1\% between 2002 and 2006.

${ }^{13}$ We measured the pairwise correlation coefficient in deviations from mean capacity over production for each pair of districts. Of the 253 correlation coefficients, the mean is 0.12 and only 95 of the coefficients are negative. We grouped the districts into 7 regions and found the average within each group. In only
} 
The inverse demand function in each district is assumed to be linear: $p=a+\lambda \theta-b q$, in which $p$ is the price, $q$ the quantity on the market, and $a$ and $b$ are two positive parameters. Uncertainty is introduced through the random variable $\theta$, assumed to be uniformly distributed on the interval $[-1 ;+1]$ with density $1 / 2$. The parameter $\lambda$ measures the range of demand variation, the case of no uncertainty corresponds to $\lambda=0$.

$N$ firms operate in the market. Each firm has access to two technologies: a home one and a foreign one. The cost function for the home technology consists of two terms: a linear investment $\operatorname{cost} c_{k}$ relative to a capacity choice denoted $k$, and a linear production cost $c_{h}{ }^{14}$ The cost function for the foreign technology involves a linear production cost $c_{f}$ and no investment cost. In the case of no uncertainty the home technology is preferred to the foreign one, $c_{h}+c_{k}<c_{f}$ and demand is high enough to make production worthwhile, $a>c_{h}+c_{k}$. Furthermore, $\lambda$ is limited so that in all realized demand states, it is worth producing with the home technology: $0 \leq \lambda \leq a-c_{h}$.

The decision process takes place in three stages. First, the firms decide their capacity $k$ relative to the home technology. Second, uncertainty is resolved for the time period in question, and the realized value of $\theta$ is revealed to the firm. Third, the production decisions $\left(q_{h}, q_{f}\right)$ using respectively the home and foreign technologies are made by the firm. It is explicitly assumed that the production decisions of any given firm do not depend on the capacity of its competitors. This assumption means that firms will not select their capacity to pre-empt competitors, but only to face demand fluctuations optimally.

Meunier and Ponssard derive the optimal capacity $k^{*}$. Consider first the case of a monopoly, $N=1$ (we show later on that the results are not substantially affected when $N>1$ ). The optimal capacity is better understood using a two dimensional diagram with axes as volatility $\lambda$ and cost of imports $c_{f}$. The diagram defines four zones, labeled from 1 to 4 (see Graph 2). The analytical expression of the optimal capacity depends on the zone. It is given in Table 2, which also provides straightforward comparative statics properties.

Qualitatively, the optimal capacity is increasing as the cost of imports increases; eventually, as one may expect, it does not depend on this cost. The influence of volatility depends on whether the cost of imports is high or low (to be precise, greater or lower than $2 c_{k}+c_{h}$ ). If it is high (along the "landlocked" vertical line), the optimal

one group was the average correlation less than the overall average (0.109 in the Midwestern group). This was due to a relatively large negative correlation between the Arkansas and Oklahoma and the lowa, Nebraska, and South Dakota districts. We note that these two districts, while close, are separated by Kansas and Missouri.

${ }^{14}$ The introduction of a fixed component in the investment cost is immaterial for the analysis. 
capacity is increasing with volatility; if it is low (along the "coastal" vertical line), it is decreasing with volatility.

\section{Graph 2: The structure of the optimal capacity as a function of volatility and the cost of imports.}

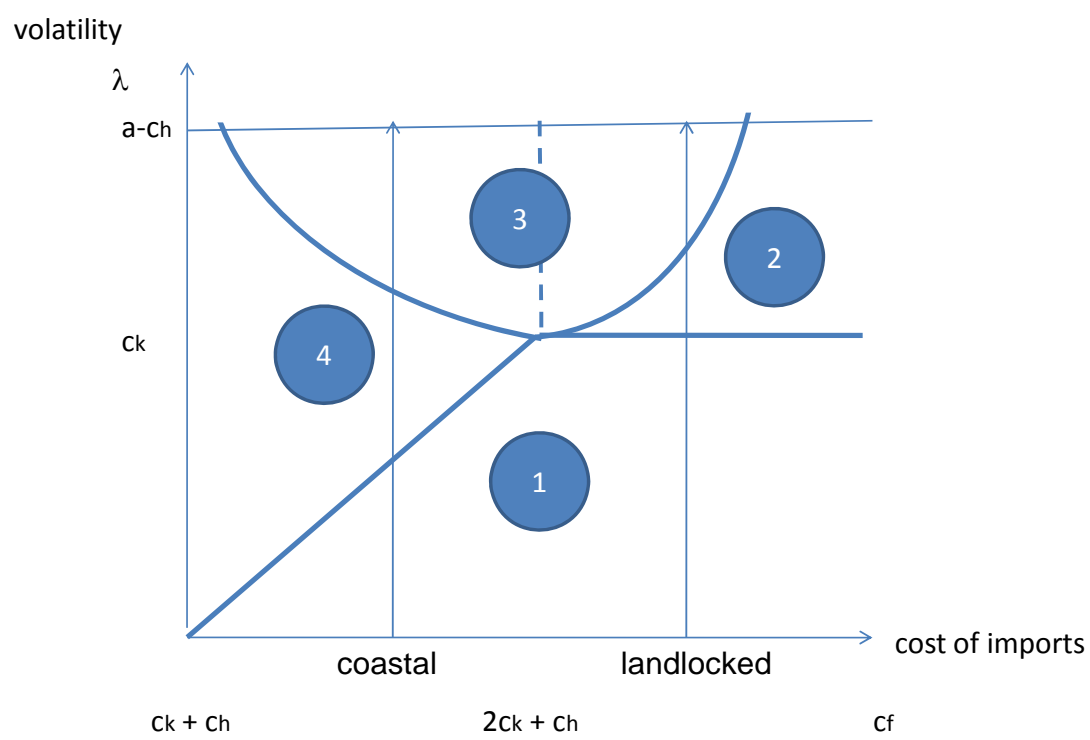

Table 3: the analytical expression of the optimal capacity and its comparative statics properties

\begin{tabular}{|c|l|l|}
\hline Zone & Optimal capacity & Comparative statics properties \\
\hline 1 & {$\left[a-c_{h}-c_{k}\right] / 2 b$} & $\begin{array}{l}\text { Independent of } c_{f} \\
\text { Independent of } \lambda\end{array}$ \\
\hline 2 & $\left.\left[a-c_{h}+\lambda-\left(2 c_{k}\right)^{1 / 2}\right)\right] / 2 b$ & $\begin{array}{l}\text { Independent of } c_{f} \\
\text { Independent in } \lambda\end{array}$ \\
\hline 3 & {$\left[a-\left(c_{h}+c_{f}\right) / 2+\lambda\left(1-2 c_{k} /\left(c_{f}-c_{h}\right)\right)\right] / 2 b$} & $\begin{array}{l}\text { Increasing in } c_{f} \\
\text { Increasing in } \lambda \text { if } c_{f}>2 c_{k}+c_{h} \\
\text { Decreasing in } \lambda \text { if } c_{f}<2 c_{k}+c_{h}\end{array}$ \\
\hline 4 & {$\left[a-c_{f}-\lambda\right] / 2 b+\left[\lambda\left(c_{f}-c_{k}-c_{h}\right)\right]^{1 / 2} / b$} & $\begin{array}{l}\text { Increasing in } c_{f} \\
\text { Decreasing in } \lambda\end{array}$ \\
\hline
\end{tabular}

A nice prediction of the model is that the higher the volatility the more important the differences between the excess capacity ratios selected by a coastal firm relative to a landlocked firm (formally it is easy to check that $\delta^{2} k^{*} / \delta \lambda \delta c_{f} \geq 0$ ). This is illustrated in Graph 3. The difference between $C$ and $D$ is larger than the difference between $A$ and $B$ This prediction will be tested. Whether the excess ratios are actually increasing with uncertainty for a landlocked district and decreasing for a coastal one depends on the 
actual value of the cost of imports relative to the critical level $2 c_{k}+c_{h}$. This prediction will also be tested.

\section{Graph 3: the excess capacity ratio in landlocked and coastal districts as a function of demand uncertainty}

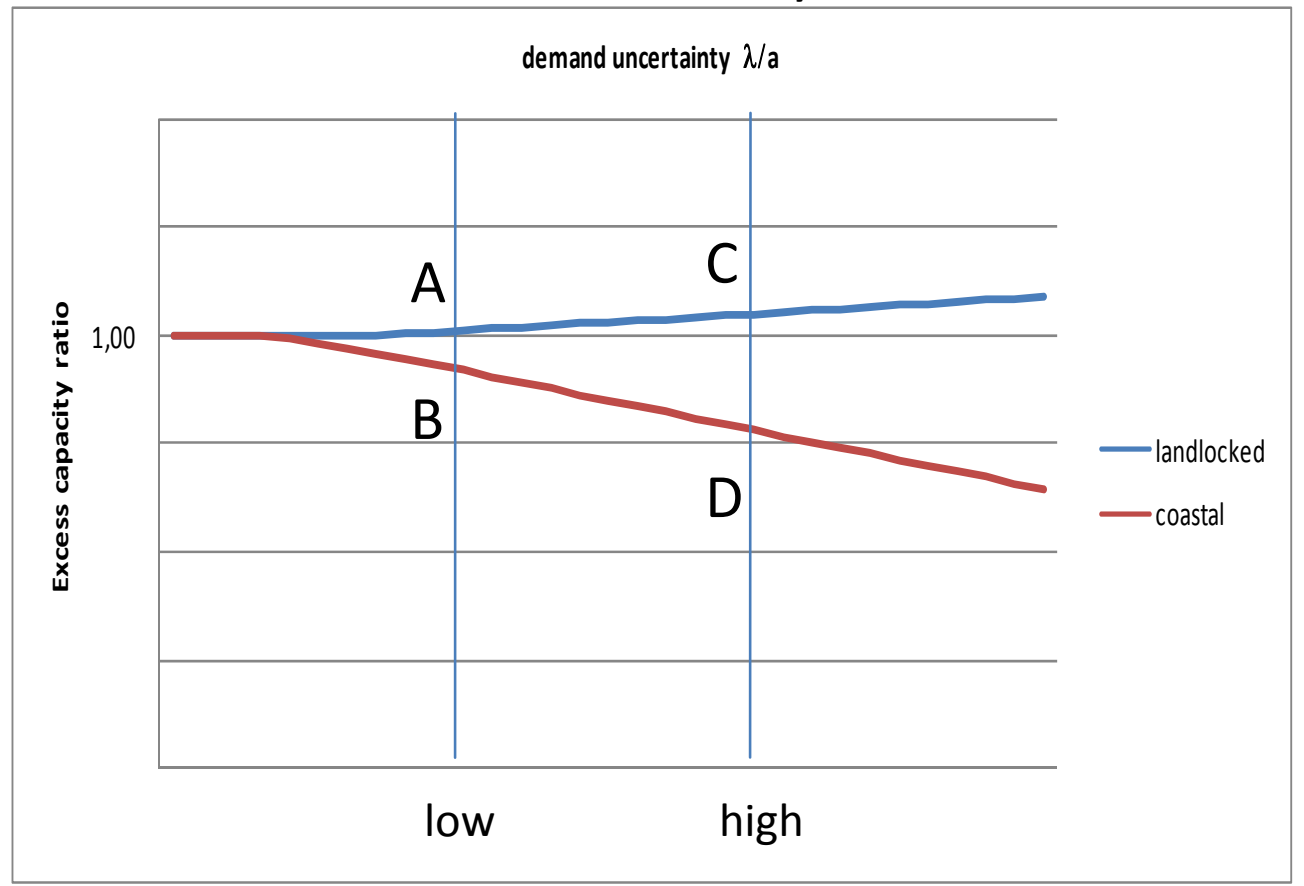

For completeness, the frontiers of the zones identified in Graph 2 are given in Table 4.

Table 4: the frontiers of the zones that define the optimal capacity

\begin{tabular}{|l|l|}
\hline Frontier & Analytical expression \\
\hline Zones 1 and 2 & $\lambda=c_{k}$ \\
\hline Zones 2 and 3 & $\lambda=\left(c_{f}-c_{h}\right)^{2} / 4 c_{k}$ \\
\hline Zones 3 and 4 & $\lambda=\left(c_{f}-c_{h}\right)^{2} / 4\left(c_{f}-c_{h}-C_{k}\right)$ \\
\hline Zones 4 and 1 & $\lambda=c_{f}-\left(c_{h}+c_{k}\right)$ \\
\hline
\end{tabular}

Consider now the case of $N$ firms, with $N>1$. Denote $k^{*}(N ; \lambda)$ the optimal capacity decision as a function of $N$ and $\lambda$. Meunier and Ponssard prove that, at the Nash equilibrium, the capacity satisfies $k^{*}(N ; \lambda)=2 k^{*}(1 ; \lambda) /(N+1)$. As a consequence, the excess capacity ratio due to the presence of uncertainty, $k^{*}(N ; \lambda) / k^{*}(N ; O)$, does not depend on the market structure, even if capacity does.

We now turn to the evaluation of the model's predictions using the US data. The table below (an excerpt from Table 5) presents excess capacity (capacity less production) divided by the level of capacity on average for the districts in each of four categories. 
These categories mirror Graph 3: landlocked and coastal districts and low and high volatility districts. We see that the excess capacity in low demand volatility districts is the same across coastal and landlocked districts; on average, $20 \%$ of capacity is unused in each of these district groups. Among high volatility districts, however, coastal districts have much lower levels of excess capacity on average than landlocked districts.

(An excerpt from) Table 5: Excess Capacity ((Capacity-Production)/Capacity) by District Group

\begin{tabular}{|c|c|c|}
\hline & \multicolumn{2}{|c|}{2006} \\
\hline & $\begin{array}{c}\text { Low } \\
\text { Volatility }\end{array}$ & $\begin{array}{c}\text { High } \\
\text { Volatility }\end{array}$ \\
\hline Landlocked & $\begin{array}{c}0.20 \\
(0.06)\end{array}$ & $\begin{array}{c}0.15 \\
(0.08)\end{array}$ \\
\hline Coastal & $\begin{array}{c}0.20 \\
(0.05)\end{array}$ & $\begin{array}{c}0.10 \\
(0.10)\end{array}$ \\
\hline
\end{tabular}

As noted in the preceding section, it is likely that the phenomenon under study appeared over the course of the 1980s, as the availability of cheap long haul transportation developed. Table 5 also shows the change in average excess capacity in each of the four categories between 1994 and 2006.

In the context of the model, if we consider that the plant efficient scale has increased over time, it makes more sense to increase average plant capacity in a landlocked district than in a coastal one. In a similar way, since we expect that dry kilns are more efficient than wet kilns, there are more investment opportunities to make this technological change in a landlocked district than in coastal one. Table 5 demonstrates that this indeed seems to be the case.

We see large percentage increases in excess capacity, average plant size, and percentage dry process plants in high volatility landlocked districts. We see the smallest percentage increases (or largest percentage decrease) in high volatility coastal districts. These broad patterns are consistent with the predictions of the model. But, since the growth rates of these variables are clouded by variation in demand growth, we now look at cross sections of the data at different points in time.

We analyze the relationship between demand volatility and the ratio of capacity to production at the start of our data sample, in 1994, and at the end, in 2006. We regress this measure of excess capacity in each district on an indicator variable for whether the district is high volatility over the time period, an indicator variable for whether it is landlocked, and the interaction of these two indicator variables. We also control for 
whether the district experiences high growth over the data period, and the interaction of the high growth and landlocked indicator variables. Table 6 presents these results for 1994 and 2006.

(Excerpt from) Table 5:

Excess Capacity

((Capacity-Production)/Capacity)

Percentage Change 1994-2006

Low Volatility High Volatility

\begin{tabular}{|c|c|c|}
\cline { 2 - 3 } Landlocked & 9.23 & 42.41 \\
& $(47.57)$ & $(109.31)$ \\
\cline { 2 - 3 } Coastal & 29.08 & -18.38 \\
& $(60.36)$ & $(94.46)$ \\
\hline
\end{tabular}

Average Plant Size ('000 metric tons)

Percentage Change 1994-2006

Low Volatility High Volatility

\begin{tabular}{|c|c|c|}
\cline { 2 - 3 } Landlocked & 28.62 & 56.65 \\
& $(15.86)$ & $(30.98)$ \\
\cline { 2 - 3 } Coastal & 18.77 & 17.59 \\
& $(21.37)$ & $(16.21)$ \\
\hline
\end{tabular}

\% Dry Process

Percentage Point Change 1994-2006

Low Volatility High Volatility

\begin{tabular}{c|c|c|}
\cline { 2 - 3 } Landlocked & $\begin{array}{c}13 \% \\
(23 \%)\end{array}$ & $\begin{array}{c}29 \% \\
(21 \%)\end{array}$ \\
\cline { 2 - 3 } Coastal & $45 \%$ & $-3 \%$ \\
& $(66 \%)$ & $(5 \%)$ \\
\hline
\end{tabular}

In panel B of Table 6, the tests of significance of the relevant linear combinations of coefficients reveal that in 1994 higher demand volatility coastal districts have 
significantly lower levels of excess capacity than low demand volatility coastal districts. High volatility landlocked districts also have somewhat lower excess capacity than low volatility landlocked districts, although this relationship is not significant. By 2006, the average level of excess capacity in high volatility coastal districts has fallen even further. There has been no corresponding reduction in landlocked districts; rather the average level of excess capacity in high volatility landlocked districts in 2006 is very similar to the level in low volatility landlocked districts.

\section{Estimation Strategy}

We now turn to analyze the patterns revealed in Table 6 in more detail. We examine the level of excess capacity in each district by investigating variation in the yearly capacity level less the mean production level in the district over time divided by the yearly capacity level. We use the mean production by district over the time period 1994-2006 in the numerator of the dependent variable here to ensure that any variation in a district over time reflects firms' decisions related to capacity choices rather than yearly fluctuations in production, which will vary systematically with annual local demand. We regress this dependent variable on district-level demand growth, demand volatility, and the interaction of each of these measures with an indicator for whether the district is landlocked or coastal. We include the landlocked indicator variable and year fixed effects as control variables. This specification reveals how variation in excess capacity is related to variation in local demand conditions in cross section.

The estimated equation is:

(1) $y_{i, t}=\alpha+\beta_{G} G_{i, t}+\beta_{V} V_{i, t}+\gamma_{G}\left(G_{i, t} * L_{i}\right)+\gamma_{G}\left(V_{i, t} * L_{i}\right)+\mu L_{i}+i . Y e a r+\varepsilon_{i, t}$

where $y_{i t}$ is the measure of excess capacity in district $i$ in year $t, G_{i t}$ and $V_{i t}$ are the yearly values of district demand growth and volatility, respectively, and $L_{i}$ is the landlocked indicator variable.

As is common in the analysis of panel data, we confront serial correlation in the independent variables since each observation of demand growth and demand volatility is constructed using data from the previous four years. The landlocked indicator variable is, of course, constant over time. Since we have only 23 districts in this study, clustering standard errors to allow for correlation within district is inappropriate. We report the robust unclustered standard errors and the standard errors produced by a nonparametric bootstrap estimation, clustering the draws in the bootstrap repetitions by district. We draw inference about the statistical significance of linear combinations of the estimated coefficients, and about the difference between linear combinations, using the bootstrapped standard errors. 
We test whether differences in the estimated coefficients are significantly different from zero, and significantly different from each other, in ways that are consistent with the predictions of the model. Starting with the group of coastal districts, we test whether there is a significant difference in excess capacity for districts at the $5^{\text {th }}$ and $95^{\text {th }}$ percentiles of district-level demand volatility. We do the same for the group of landlocked districts. We then ask whether there is a significant difference in levels of excess capacity between coastal and landlocked districts at the $5^{\text {th }}$ percentile of demand volatility and at the $95^{\text {th }}$ percentile of demand volatility.

The estimation described in equation (1) does not include district fixed effects and so district-level factors other than whether the district is landlocked may be contributing to the results. The second specification we estimate includes district fixed effects in equation (1), and hence omits non-time varying district characteristics. This specification tells us whether changes in demand growth or volatility within a district are associated with changes in the level of excess capacity which, since the denominator is timeinvariant, corresponds to changes in the level of capacity within-district. Once again, we present the results with both unclustered and bootstrapped standard errors.

Using the output from this specification, we ask whether a change capacity is associated with an increase in volatility for different district groups, using the bootstrapped standard errors. The impact of the change in volatility is restricted to be constant at all levels of growth or volatility in this linear specification. Hence, to test whether a change in demand volatility is associated with a change in the level of excess capacity in coastal districts, we examine the significance of the coefficient estimate for demand volatility. To test whether a change in demand volatility is associated with a change in capacity in landlocked districts, we test whether the linear combination of the coefficients on demand volatility and the interaction of demand volatility and the landlocked indicator is significantly different from zero. We then test whether changes in demand volatility have significantly different effects on capacity in coastal versus landlocked districts.

Last, we note that our data contains some information on the quality of capacity by district. We know that, in this industry, larger plants are on average more efficient and also that dry process plants are more efficient that wet process plants. The model has similar predictions for upgrading the quality of capacity as for the amount of capacity. Accordingly, we examine whether plant size and the percentage of dry process capacity within-district are related to demand uncertainty in a way consistent with the predictions of the model. We estimate equation (1) including district fixed effects with the average plant size and the percentage of dry process capacity as the dependent variables. 


\section{Results}

Panel A of Table 7 presents the results from the first regression specification, equation (1). Columns 1 and 2 reveal that, on average, greater volatility is associated with lower levels of excess capacity controlling for demand growth and production levels. This appears to contradict previous models which consider only one production technology and predict a positive association between demand volatility and capacity. Higher levels of demand growth are positively associated with excess capacity, but not significantly so. Columns 3 and 4 show that the negative relationship between demand volatility and excess capacity varies across districts by separating the data into coastal and landlocked districts and investigating whether the relationship holds in each subgroup.

We see that higher volatility is associated with lower excess capacity only in coastal districts. Panel B of Table 7 constructs the linear combinations of relevant coefficient estimates for different groups of districts. The level of excess capacity is significantly lower in coastal districts with higher demand volatility than in coastal districts with lower demand volatility. For landlocked districts, where high transport costs allows firms access to only one production technology, the difference in excess capacity between high and low volatility districts is not significantly different from zero. Moreover, we note that excess capacity in high volatility coastal districts is significantly lower than excess capacity in high volatility landlocked districts.

The results for the second specification, equation (1) including district fixed effects, are given in Table 8. Changes in capacity are on average positively associated with changes in demand volatility, although the relationship is not significant with the bootstrapped standard errors. Columns 3 and 4 show that there is a significant positive coefficient on the interaction of demand volatility and the variable indicating that a district is landlocked. Panel B of the table contains the linear combinations of estimated coefficients and the analysis of significant differences. We see that there is a positive relationship between changes in volatility and changes in capacity in landlocked districts that is significant at the $5 \%$ level. There is also a significant difference in the response to changes in volatility between landlocked and coastal districts - the relationship is significantly more positive in landlocked districts.

Table 9 contains the results for the estimation of equation (1) including district fixed effects with average plant size and the percentage of dry process plants as the dependent variables. The findings for average plant size are consistent with the model's predictions. An increase in demand volatility is, on average, associated with an increase in the average plant size in a district. This positive relationship is, however, limited to landlocked districts. The tests of significance of the linear combinations of the coefficients reveal that the slope of the relationship between average plant size and demand volatility is significantly more positive for landlocked than for coastal districts. 
The corresponding results in Table 9 for the percentage of dry process plants offer no empirical support of the model's predictions. There are no significant differences in the relationship between percentage dry process and demand volatility and whether a district is landlocked. We note, though, that many districts began the data period with $100 \%$ dry process plants, as shown in Table 1, and offer no variation throughout the period from which to draw inference.

\section{Concluding comments}

This paper provides some empirical evidence about the theory of irreversible decisions under uncertainty at the micro-level. It shows that the capacity decisions of US cement firms are consistent with the theory: the amount of domestic excess capacity over an uncertain business cycle depends on the relative cost of imports, which varies from coastal to landlocked markets. The positive relationship between demand uncertainty and investment predicted by theory models with only one technology is present in landlocked districts where imports are prohibitively costly. The paper also provides a new rationale to explain the co-existence of home production and imports in the US cement market by large multinational firms. Adding demand volatility to the proximityconcentration tradeoff described in Brainard (1997) can explain why we see imports and domestic production - even in the long run - in districts where the variable cost of imported cement is not too much greater than domestic production. The greater the demand volatility in these districts, the larger the average ratio of imports to FDI.

Specifically, we show that coastal districts with high demand volatility have significantly lower levels of excess capacity than coastal districts with low demand volatility, controlling for the level of demand and recent demand growth. Landlocked districts look very different. Investment in capacity, and the average plant size, both increase with demand volatility in these districts.

We are able to infer significant differences in the relationship between excess capacity and demand volatility between coastal and landlocked districts even though our analysis is based on fairly aggregated data and covers only 12 years. A simple regression with 23 observations of the average district-level excess capacity on indicator variables for whether the district is landlocked, whether it has high demand volatility on average over the entire period, and the interaction of the two, while allowing for the role of demand growth to vary with whether the district is coastal or not, reveals that high demand volatility coastal districts have significantly lower levels of excess capacity than when demand volatility is low. This suggests to us that our more detailed analysis is capturing meaningful correlations in the data.

A number of other caveats should be made. Some important features of the industry are not taken into account explicitly in the model or the empirical work. These include the existence of independent importers (pure traders, grinding stations, ready mix companies...), strategic behavior for preemption purposes, and further local variation in 
geography of each market (large urban areas or other types of market). Extending the model to incorporate these features is left to future research. It may also be interesting to extend the empirical analysis to other cement markets. Preliminary analysis using data from the industry source Cembureau reveals that coastal countries, such as the UK, have significantly lower levels of excess capacity than landlocked countries such as Switzerland. A country like Spain exhibits both landlocked and coastal markets and, as such, is a good candidate for inclusion in a further test, but detailed regional data is less readily available for Spain than for the US.

From a policy perspective, this paper provides a contribution to the current debate on the impact of unilateral climate policies. The EU implemented a unilateral policy in 2004 with a cap and trade scheme for carbon intensive industry (such as cement production, electricity, glass, oil refineries, steel...). Other industrialized countries such as the US may engage in similar policies in the future. This has triggered an intense debate about the effectiveness of unilateral policies in sectors that are subject to international competition, which includes most of the carbon intensive sectors except electricity (Grubb and Neuhoff, 2006). In theory, we expect a reduction in market share and a decline in investment from home producers, and a concomitant increase in imports from countries with no similar climate policy (for a discussion in the cement case see for instance Demailly and Quirion, 2006 or Ponssard and Walker, 2008). This would reduce the efficiency of unilateral policies in curbing worldwide emissions through the so-called leakage effect - an increase in foreign emissions substituting for any decrease in domestic emissions.

So far there is very little empirical evidence to support the conclusions derived from these analytical models (Ellerman et al., 2010). Still, the debate remains open since existing empirical work cannot yet capture long run effects. This paper provides an important indirect contribution. It substantiates that there are indeed long term effects on investment levels associated with a change in the relative costs of imports when demand is subject to uncertainty. The recent failure of the United Nations Climate Change Conference in Copenhagen to agree to implement a uniform carbon tax across international markets reinforces the importance of these considerations. 


\section{References}

Arrow, K. and A. Fisher. 1974. "Environmental Preservation, Uncertainty, and Irreversibility." The Quarterly Journal of Economics. 88(2): 312-319.

Bell, G. and J. Campa. 1997. "Irreversible Investments and Volatile Markets." The Review of Economics and Statistics. 79: 79-97.

Blonigen, B. 2001. "In Search of Substitution between Foreign Production and Exports." Journal of International Economics. 53: 81-104.

Bloom, N., S. Bond, and J. Van Reenen. 2007. "Uncertainty and Investment Dynamics." The Review of Economic Studies. 74(2): 391-415.

Brainard. L. 1997. "An Empirical Assessment of the Proximity-Concentration Trade-off Between Multinational Sales and Trade." American Economic Review. 87(4): 520-544

Campa, J. and L. Goldberg. 1995. "Investment in manufacturing, exchange rates and external exposure." Journal of International Economics. 38: 297-320.

Carruth, A., A. Dickerson, and A. Henley. 2000. "What do we know about Investment under Uncertainty?" Journal of Economic Surveys. 14(2): 119-154.

Cembureau. 2008. “World Statistical Review. 1996-2008”. http://www.cembureau.be/

Collomb B. and J.-P. Ponssard. 2004. Creative management in mature capital intensive industries: the case of cement in "Creative and Innovative Management", A. Charnes, W.W. Cooper (ed.), Ballinger, Cambridge.

D’Aspremont Cl., D. Encaoua and J.-P. Ponssard. 2000. Competition policy and game theory: reflection based on the cement industry case. In "Market Structure and Competition Policy", (G. Norman and J. F. Thisse eds.), ch.1, 9-30, Cambridge University Press.

Demailly, D., and P. Quirion. 2006. "CO2 abatement, competitiveness and leakage in the European cement industry under the EU ETS: grandfathering versus output-based allocation", Climate Policy 6, 93-113.

Demers, M. 1991. "Investment under Uncertainty, Irreversibility and the Arrival of Information Over Time." The Review of Economic Studies. 58(2): 333-350.

Dixit, A., 1980. "The role of investment in entry-deterrence". Economic Journal, 90: 95106. 
Dixit, A., and R. Pindyck. 1992. "Investment Under Uncertainty." Princeton: Princeton University Press.

Ellerman, D., F. J. Convery, and C. de Perthuis. 2010. "Pricing Carbon, The European Union Emissions Trading Scheme." Cambridge University Press.

Favero, C., M. H. Pesaran, and S. Sharma. 1994. "A duration model of irreversible oil investment: Theory and empirical evidence." Journal of Applied Econometrics. 9(S1): S95-S112.

Gabszewicz, J. and S. Poddar. 1997. "Demand Fluctuations and Capacity Utilization under Duopoly." Economic Theory. 10(1): 131-146.

Ghemawat, P., 1984. "Capacity expansion in the titanium dioxide industry." Journal of Industrial Economics 33: 145-163

Ghemawat P. and C. Thomas. 2008. "Strategic Interaction across Countries and Multinational Agglomeration: An Application to the Cement Industry." Management Science. 54, 1980-1996.

Goldberg, L. 1993. "Exchange rates and investment in United States industry." Review of Economics and Statistics. 75(4): 575-589.

Grubb, M., and K. Neuhoff. 2006. "Allocation and competitiveness in the EU emissions trading scheme: policy overview", Climate Policy 6, 7-30.

Guiso, L., and G. Parigi. 1999. "Investment and Demand Uncertainty." The Quarterly Journal of Economics. 114(1): 185-227.

Head, K., and J. Reis. 2001. "Overseas investment and firm exports." Review of International Economics. 9(1): 108-122.

Henry, C. 1974. "Investment decisions under uncertainty: The "irreversibility effect"." American Economic Review. 64(6): 1006-1012.

Hurn, A.S., and R. Wright. 1994. "Geology or economics? Testing models of irreversible investment using North Sea Oil Data." Economic Journal. 104: 363-371.

Kogut, B. and N. Kulatilaka. 1994. "Operating Flexibility, Global Manufacturing, and the Option Value of a Multinational Network". Management Science. 40(1): 123-139.

Leahy, J. and T. Whited. 1996. "The effect of uncertainty on investment: some stylized facts." Journal of Money, Credit and Banking. 28(1): 64-83. 
Lieberman, M.B., 1987. "Excess capacity as a barrier to entry: An empirical appraisal." Journal of Industrial Economics, 35: 607-627.

Mathis, S., and Koscianski, J., 1997. “Excess capacity as a barrier to entry in the US titanium industry". International Journal of Industrial Organization, 15(2): 263-281.

Meunier G. and J.-P. Ponssard. 2009. "Capacity decisions with demand fluctuations and carbon leakage." WP Ecole Polytechnique, August.

Ponssard J.-P., H. Tanguy and D. Sevy. 2007. Economie de l'entreprise: stratégie, organisation et finance de l'entreprise. Les Editions de l'Ecole Polytechnique, Palaiseau, 282 pages, deuxième édition.

Ponssard, J. and N. Walker. 2008. "EU emissions trading and the cement sector: a spatial competition analysis." Climate Policy. 8: 467-493.

Robb, R., and N. Vettas. 2003. "Foreign Direct Investment and Exports with Growing Demand." The Review of Economic Studies. 70(3): 629-648.

Rothschild, M. and J. Stiglitz. 1970. "Increasing risk i: A definition." Journal of Economic Theory. 2: 225-243.

Rothschild, M. and J. Stiglitz. 1971. "Increasing risk ii: Its economic consequences." Journal of Economic Theory. 3: 66-84.

Salvo, A., 2010. "Inferring Market Power under the Threat of Entry: The Case of the Brazilian Cement Industry.” RAND Journal of Economics, 41(2): 326-350.

Spence, A.M., 1977. "Entry, capacity, investment and oligopolistic pricing". Bell Journal of Economics 8: 534-544.

U.S. Geological Survey. 1994-2006. "Minerals Yearbook. Cement". U.S. Department of the Interior. http://minerals.usgs.gov/ 
Table 1: Summary Statistics

\begin{tabular}{|c|c|c|c|c|c|c|c|c|c|c|}
\hline \multirow[b]{2}{*}{\begin{tabular}{|l|} 
\\
District \\
Number District Name
\end{tabular}} & \multicolumn{5}{|c|}{1994} & \multicolumn{5}{|c|}{2006} \\
\hline & $\begin{array}{c}\text { Demand } \\
000 \text { metric tons }\end{array}$ & $\begin{array}{l}\text { Active Plants* } \\
\#\end{array}$ & $\begin{array}{c}\text { Capacity } \\
000 \text { metric tons }\end{array}$ & $\begin{array}{l}\text { Average Plant } \\
\text { Size } \\
000 \text { metric tons }\end{array}$ & $\begin{array}{l}\text { Percentage Dry } \\
\text { (or Wet and } \\
\text { Dry)* } \\
\%\end{array}$ & $\begin{array}{l}\text { Demand } \\
000 \text { metric tons }\end{array}$ & $\begin{array}{c}\text { Active Plants* } \\
\quad \#\end{array}$ & $\begin{array}{c}\text { Capacity } \\
000 \text { metric tons }\end{array}$ & $\begin{array}{l}\text { Average Plant } \\
\text { Size } \\
000 \text { metric tons }\end{array}$ & $\begin{array}{c}\text { Percentage Dry } \\
\text { (or Wet and } \\
\text { Dry)* } \\
\%\end{array}$ \\
\hline 1 Alabama & 1432 & 5 & 4573 & 914.6 & $100 \%$ & 1798 & 5 & 6036 & 1207.2 & $100 \%$ \\
\hline 2 Alaska, Hawaii, Oregon, Washington & 3168 & 4 & 2295 & 573.8 & $75 \%$ & 4307 & 4 & 2540 & 635.0 & $67 \%$ \\
\hline 3 Arizona, New Mexico & 2823 & 3 & 2288 & 762.7 & $100 \%$ & 5511 & 3 & 3310 & 1103.3 & $100 \%$ \\
\hline 4 Arkansas, Oklahoma & 1994 & 4 & 2694 & 673.5 & $50 \%$ & 2730 & 4 & 3260 & 815.0 & $50 \%$ \\
\hline 5 California, Northern & 2872 & 3 & 2776 & 925.3 & $100 \%$ & 4761 & 3 & 2853 & 951.0 & $100 \%$ \\
\hline 6 California, Southern & 5328 & 8 & 7933 & 991.6 & $100 \%$ & 9549 & 8 & 10238 & 1279.8 & $100 \%$ \\
\hline 7 Colorado, Wyoming & 2021 & 4 & 2377 & 594.3 & $75 \%$ & 3107 & 3 & 3450 & 1150.0 & $100 \%$ \\
\hline 8 Florida & 5623 & 6 & 4382 & 730.3 & $50 \%$ & 11180 & 7 & 7301 & 1043.0 & $100 \%$ \\
\hline 9 Georgia, Virginia, West Virginia, South Carolina, Maryland & 9461 & 11 & 8586 & 780.5 & $60 \%$ & 14716 & 10 & 11636 & 1163.6 & $78 \%$ \\
\hline 10 Idaho, Montana, Nevada, Utah & 3112 & 6 & 2422 & 403.7 & $33 \%$ & 5443 & 6 & 3750 & 625.0 & $50 \%$ \\
\hline 11 Illinois & 3593 & 4 & 3217 & 804.3 & $100 \%$ & 4555 & 4 & 3420 & 855.0 & $100 \%$ \\
\hline 12 Indiana & 1876 & 4 & 2867 & 716.8 & $50 \%$ & 2173 & 4 & 3720 & 930.0 & $75 \%$ \\
\hline 13 lowa, Nebraska, South Dakota & 3112 & 6 & 5758 & 959.7 & $100 \%$ & 4182 & 5 & 6048 & 1209.6 & $100 \%$ \\
\hline 14 Kansas & 1277 & 4 & 1801 & 450.3 & $50 \%$ & 1546 & 4 & 3329 & 832.3 & $75 \%$ \\
\hline 15 Kentucky, Mississippi, Tennessee & 3794 & 4 & 2128 & 532.0 & $50 \%$ & 4765 & 4 & 3700 & 925.0 & $75 \%$ \\
\hline 16 Michigan, Wisconsin & 5992 & 5 & 6532 & 1306.4 & $67 \%$ & 6578 & 5 & 7328 & 1465.6 & $67 \%$ \\
\hline 17 Missouri & 2386 & 5 & 5059 & 1011.8 & $60 \%$ & 2626 & 5 & 6958 & 1391.6 & $60 \%$ \\
\hline 18 New York, Maine & 3691 & 5 & 4141 & 828.2 & $20 \%$ & 5207 & 5 & 4203 & 840.6 & $50 \%$ \\
\hline 19 Ohio & 3482 & 3 & 1588 & 529.3 & $50 \%$ & 3727 & 2 & 1304 & 652.0 & $50 \%$ \\
\hline 20 Pennsylvania, Eastern & 1967 & 8 & 4878 & 609.8 & $71 \%$ & 2172 & 7 & 4530 & 647.1 & $67 \%$ \\
\hline 21 Pennsylvania, Western & 2529 & 4 & 2009 & 502.3 & $25 \%$ & 3030 & 3 & 1770 & 590.0 & $33 \%$ \\
\hline 22 Texas, Northern & 3817 & 6 & 4512 & 752.0 & $50 \%$ & 6499 & 6 & 7594 & 1265.7 & $67 \%$ \\
\hline 23 Texas, Southern & 5759 & 6 & 5529 & 921.5 & $100 \%$ & 10668 & 6 & 5850 & 975.0 & $100 \%$ \\
\hline
\end{tabular}

\begin{tabular}{|c|c|c|c|c|c|}
\hline \multicolumn{6}{|c|}{ 1994-2006 } \\
\hline $\begin{array}{l}\text { District } \\
\text { Number District Name }\end{array}$ & $\begin{array}{l}\text { Landlocked } \\
\text { Indicator }\end{array}$ & $\begin{array}{l}\text { High Demand } \\
\text { Growth } \\
\text { Indicator }\end{array}$ & $\begin{array}{l}\text { High Demand } \\
\text { Volatility } \\
\text { Indicator }\end{array}$ & $\begin{array}{l}\text { Mean Demand } \\
\text { Growth } 1994- \\
2006\end{array}$ & $\begin{array}{l}\text { Mean Demand } \\
\text { Volatility 1994- } \\
2006\end{array}$ \\
\hline 1 Alabama & 1 & 0 & 0 & 0.020 & 0.024 \\
\hline 2 Alaska, Hawaii, Oregon, Washington & 0 & 0 & 0 & 0.020 & 0.012 \\
\hline 3 Arizona, New Mexico & 1 & 1 & 0 & 0.059 & 0.024 \\
\hline 4 Arkansas, Oklahoma & 1 & 0 & 1 & 0.031 & 0.037 \\
\hline 5 California, Northern & 0 & 1 & 0 & 0.053 & 0.027 \\
\hline 6 California, Southern & 0 & 1 & 1 & 0.064 & 0.032 \\
\hline 7 Colorado, Wyoming & 1 & 1 & 1 & 0.043 & 0.041 \\
\hline 8 Florida & 0 & 1 & 0 & 0.061 & 0.023 \\
\hline 9 Georgia, Virginia, West Virginia, South Carolina, Maryland & 0 & 1 & 0 & 0.033 & 0.021 \\
\hline 10 Idaho, Montana, Nevada, Utah & 1 & 1 & 0 & 0.037 & 0.025 \\
\hline 11 llinois & 1 & 0 & 0 & 0.021 & 0.028 \\
\hline 12 Indiana & 1 & 0 & 0 & 0.014 & 0.028 \\
\hline 13 lowa, Nebraska, South Dakota & 1 & 0 & 0 & 0.026 & 0.016 \\
\hline 14 Kansas & 1 & 0 & 1 & 0.011 & 0.030 \\
\hline 15 Kentucky, Mississippi, Tennessee & 1 & 0 & 1 & 0.013 & 0.032 \\
\hline 16 Michigan, Wisconsin & 1 & 0 & 0 & 0.014 & 0.026 \\
\hline 17 Missouri & 1 & 0 & 1 & 0.018 & 0.030 \\
\hline 18 New York, Maine & 0 & 0 & 0 & 0.029 & 0.026 \\
\hline 19 Ohio & 1 & 0 & 0 & 0.008 & 0.025 \\
\hline 20 Pennsylvania, Eastern & 0 & 0 & 1 & 0.016 & 0.044 \\
\hline 21 Pennsylvania, Western & 1 & 0 & 1 & 0.023 & 0.042 \\
\hline 22 Texas, Northern & 1 & 1 & 1 & 0.054 & 0.046 \\
\hline 23 Texas, Southern & 0 & 1 & 0 & 0.048 & 0.028 \\
\hline
\end{tabular}

* We take the number of plants from Table 3 of the USGS Minerals Survey in each year. The percentage dry technology is taken from Table 5, which is based on the number of white cement plants. pants is on occasion less than the total number of plants. This means the percentage dry technology does not reflect a percentage of the total number of plants. 
Table 2: Pairwise Correlations in 1998 and 2006

(Earliest year is 1998 since demand growth and volatility are first measured for this year, based on data from 1994-1998)

\begin{tabular}{|c|c|c|c|c|c|c|c|c|}
\hline 1998 & Demand & Number of Plants & Capacity & Production & Average Plant Size & $\begin{array}{l}\text { Percentage Dry (or } \\
\text { Wet and Dry) } \\
\text { Process }\end{array}$ & Demand Growth & Demand Volatility \\
\hline Demand & 1 & & & & & & & \\
\hline Number of Plants & 0.59 & 1 & & & & & & \\
\hline Capacity & 0.67 & 0.81 & 1 & & & & & \\
\hline Production & 0.62 & 0.79 & 0.98 & 1 & & & & \\
\hline Average Plant Size & 0.37 & 0.09 & 0.65 & 0.62 & 1 & & & \\
\hline Percentage Dry (or Wet and Dry) Process & 0.02 & 0.05 & 0.26 & 0.30 & 0.40 & 1 & & \\
\hline Demand Growth & 0.37 & 0.26 & 0.27 & 0.26 & 0.14 & 0.34 & 1 & \\
\hline Demand Volatility & -0.24 & -0.01 & -0.15 & -0.04 & -0.27 & -0.28 & -0.10 & 1 \\
\hline
\end{tabular}

\begin{tabular}{|c|c|c|c|c|c|c|c|c|}
\hline 2006 & Demand & Number of Plants & Capacity & Production & Average Plant Size & $\begin{array}{l}\text { Percentage Dry (or } \\
\text { Wet and Dry) } \\
\text { Process }\end{array}$ & Demand Growth & Demand Volatility \\
\hline Demand & 1 & & & & & & & \\
\hline Number of Plants & 0.71 & 1 & & & & & & \\
\hline Capacity & 0.71 & 0.87 & 1 & & & & & \\
\hline Production & 0.67 & 0.89 & 0.99 & 1 & & & & \\
\hline Average Plant Size & 0.31 & 0.32 & 0.71 & 0.68 & 1 & & & \\
\hline Percentage Dry (or Wet and Dry) Process & 0.29 & 0.15 & 0.31 & 0.33 & 0.47 & 1 & & \\
\hline Demand Growth & 0.56 & 0.31 & 0.36 & 0.38 & 0.30 & 0.48 & 1 & \\
\hline Demand Volatility & -0.25 & -0.05 & -0.09 & 0.00 & -0.06 & -0.26 & 0.10 & 1 \\
\hline
\end{tabular}


Table 5: Capacity-related Variables by District Group, 1994, 2006, and 1994-2006

(Standard Deviations, across districts in each group, in parentheses)

\section{Excess Capacity ((Capacity-Production)/Capacity)}

\section{4}

Low Volatility High Volatility

Landlocked

Coastal

\begin{tabular}{|c|c|}
\hline 0.20 & 0.13 \\
$(0.09)$ & $(0.07)$ \\
& \\
\hline & \\
0.19 & 0.15 \\
$(0.08)$ & $(0.04)$ \\
\hline
\end{tabular}

Average Plant Size ('000 metric tons)

1994

Low Volatility High Volatility

Landlocked

Coastal

\begin{tabular}{|c|c|}
\hline 800 & 645 \\
$(276)$ & $(191)$ \\
& \\
\hline 793 & 801 \\
$(132)$ & $(270)$ \\
\hline
\end{tabular}

1994

Low Volatility High Volatility

\begin{tabular}{|c|c|}
\hline $75 \%$ & $51 \%$ \\
$(28 \%)$ & $(15 \%)$ \\
& \\
\hline & \\
$68 \%$ & $86 \%$ \\
$(31 \%)$ & $(20 \%)$ \\
\hline
\end{tabular}

\section{\% Dry Process}

Landlocked

Coastal
2006 Low Volatility High Volatility

\begin{tabular}{|c|c|}
\hline 0.20 & 0.15 \\
$(0.06)$ & $(0.08)$ \\
& \\
\hline & \\
0.20 & 0.10 \\
$(0.05)$ & $(0.10)$ \\
\hline
\end{tabular}

2006

Low Volatility High Volatility

\begin{tabular}{|c|c|}
\hline 1006 & 996 \\
$(293)$ & $(284)$ \\
& \\
\hline & \\
935 & 963 \\
$(181)$ & $(447)$ \\
\hline
\end{tabular}

2006 Low Volatility High Volatility

\begin{tabular}{|c|c|}
\hline $80 \%$ & $66 \%$ \\
$(23 \%)$ & $(21 \%)$ \\
& \\
\hline & \\
$82 \%$ & $83 \%$ \\
$(21 \%)$ & $(24 \%)$ \\
\hline
\end{tabular}

Percentage Change 1994-2006 Low Volatility High Volatility

\begin{tabular}{|c|c|}
\hline 9.23 & 42.41 \\
$(47.57)$ & $(109.31)$ \\
\hline & \\
\hline & \\
$(60.08$ & -18.38 \\
& $(94.46)$ \\
\hline
\end{tabular}

Percentage Change 1994-2006 Low Volatility High Volatility

\begin{tabular}{|c|c|}
\hline $\begin{array}{c}28.62 \\
(15.86)\end{array}$ & $\begin{array}{c}56.65 \\
(30.98)\end{array}$ \\
\hline $\begin{array}{c}18.77 \\
(21.37)\end{array}$ & $\begin{array}{c}17.59 \\
(16.21)\end{array}$ \\
\hline
\end{tabular}

Percentage Point Change 1994-2006

Low Volatility High Volatility

\begin{tabular}{|c|c|}
\hline $13 \%$ & $29 \%$ \\
$(23 \%)$ & $(21 \%)$ \\
& \\
\hline & \\
$(65 \%)$ & $-3 \%$ \\
& $(5 \%)$ \\
\hline
\end{tabular}


Table 6: Excess capacity, in high and low volatility districts, landlocked and coastal. 1994 and 2006.*

\begin{tabular}{|lcc|} 
Panel A: Regression Output & & \\
\hline COEFFICIENT & Excess Capacity & Excess Capacity \\
& 1994 & 2006 \\
\hline High Demand Growth Indicator & $-0.08^{\star *}$ & 0.09 \\
& {$[0.04]$} & {$[0.07]$} \\
High Demand Volatility Indicator & $-0.11^{\star \star \star}$ & $-0.13^{\star}$ \\
& {$[0.03]$} & {$[0.07]$} \\
Landlocked * High Demand Growth & -0.03 & -0.01 \\
& {$[0.09]$} & {$[0.08]$} \\
Landlocked * High Demand Volatility & -0.03 & 0.14 \\
& {$[0.08]$} & {$[0.08]$} \\
Landlocked & -0.06 & 0.03 \\
& {$[0.06]$} & {$[0.04]$} \\
Constant & $0.19^{\star * \star}$ & $0.20^{\star * \star}$ \\
& {$[0.03]$} & {$[0.03]$} \\
Observations & 23 & 23 \\
R-squared & 0.37 & 0.30 \\
\hline
\end{tabular}

R-squared

Robust standard errors in brackets

${ }^{* \star \star} p<0.01,{ }^{* \star} p<0.05,{ }^{*} p<0.1$

*Excess capacity is measured as (Capacity-Production)/Capacity for year district in each year.

Panel B: Tests of significance of the differences in excess capacity across district groups, based on bootstrapped standard errors.

Significant difference across

1994

Low volatility

High volatility

Coastal

Landlocked

\begin{tabular}{|c|c|}
\hline 0 & $\begin{array}{c}-0.06 \\
{[0.06]}\end{array}$ \\
\hline $\begin{array}{c}-0.11^{\star * *} \\
{[0.03]}\end{array}$ & $\begin{array}{c}-0.19^{\star \star} \\
{[0.08]}\end{array}$ \\
\hline
\end{tabular}

No

2006

Low volatility

High volatility
Significant difference across columns? 
Table 7: Cross Section. Excess Capacity.*

Panel A: Regression Output

\begin{tabular}{|c|c|c|c|c|}
\hline VARIABLES & $\begin{array}{c}1 \\
\text { Excess Capacity }\end{array}$ & $\begin{array}{c}2 \\
\text { Excess Capacity }\end{array}$ & $\begin{array}{c}3 \\
\text { Excess Capacity }\end{array}$ & $\begin{array}{c}4 \\
\text { Excess Capacity }\end{array}$ \\
\hline Demand Growth & $\begin{array}{c}0.10 \\
{[0.30]}\end{array}$ & $\begin{array}{c}0.10 \\
{[0.58]}\end{array}$ & $\begin{array}{l}-0.03 \\
{[0.49]}\end{array}$ & $\begin{array}{l}-0.03 \\
{[0.79]}\end{array}$ \\
\hline Demand Volatility & $\begin{array}{l}-0.64 \\
{[0.57]}\end{array}$ & $\begin{array}{l}-0.64 \\
{[0.83]}\end{array}$ & $\begin{array}{l}-2.89 * \star \star \\
{[0.88]}\end{array}$ & $\begin{array}{c}-2.89 \star \star \star \\
{[0.83]}\end{array}$ \\
\hline Landlocked * Demand Growth & & & $\begin{array}{c}0.13 \\
{[0.51]}\end{array}$ & $\begin{array}{c}0.13 \\
{[0.87]}\end{array}$ \\
\hline Landlocked * Demand Volatility & & & $\begin{array}{c}3.53^{\star \star \star} \\
{[1.07]}\end{array}$ & $\begin{array}{c}3.53^{\star \star \star} \\
{[1.30]}\end{array}$ \\
\hline Landlocked & & & $\begin{array}{c}-0.10^{\star \star} \\
{[0.04]}\end{array}$ & $\begin{array}{c}-0.10^{\star \star} \\
{[0.05]}\end{array}$ \\
\hline Constant & $\begin{array}{c}0.26^{\star \star \star} \\
{[0.03]}\end{array}$ & $\begin{array}{l}0.26^{\star \star *} \\
{[0.04]}\end{array}$ & $\begin{array}{l}0.34^{\star \star *} \\
{[0.04]}\end{array}$ & $\begin{array}{l}0.34^{\star \star *} \\
{[0.04]}\end{array}$ \\
\hline Year Fixed Effects & $\mathrm{Y}$ & $\mathrm{Y}$ & $\mathrm{Y}$ & $\mathrm{Y}$ \\
\hline Standard Errors & Unclustered & Bootstrapped & Unclustered & Bootstrapped \\
\hline Observations & 207 & 207 & 207 & 207 \\
\hline R-squared & 0.19 & 0.19 & 0.22 & 0.22 \\
\hline
\end{tabular}

Robust standard errors in brackets

*** $p<0.01,{ }^{* \star} p<0.05,{ }^{*} p<0.1$

*The dependent variable is yearly capacity less the mean production level for the district divided by the yearly capacity level. Any changes over time within a district hence reflect changes in capacity.

Panel B: Tests of significance of the differences in excess capacity across district groups, based on bootstrapped standard errors From column 4

\begin{tabular}{|c|c|c|}
\hline Coastal & Landlocked & $\begin{array}{l}\text { Significant diff } \\
\text { across colur }\end{array}$ \\
\hline $\begin{array}{c}-0.03^{\star \star \star} \\
{[0.01]}\end{array}$ & $\begin{array}{c}-0.10^{\star \star} \\
{[0.04]}\end{array}$ & No \\
\hline $\begin{array}{c}-0.16 \star \star \star \star \\
{[0.05]}\end{array}$ & $\begin{array}{l}-0.07 \\
{[0.04]}\end{array}$ & Yes** \\
\hline
\end{tabular}

Significant difference across rows? $\quad$ Nes ${ }^{\star \star \star} \quad$ No


Table 8: Panel, Excess Capacity.*

Panel A: Regression Output

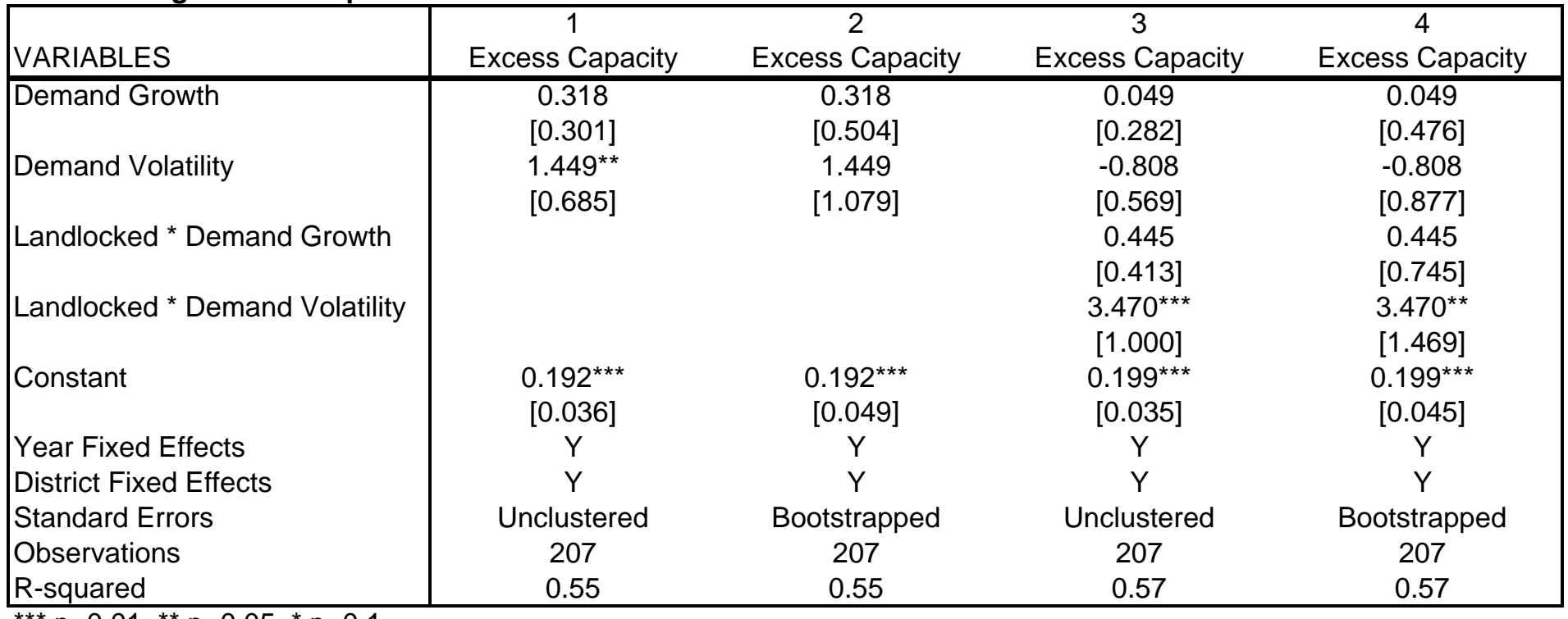

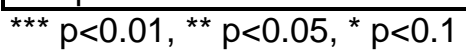

Robust standard errors in brackets

*The dependent variable is yearly capacity less the mean production level for the district divided by the yearly capacity level.

Any changes over time within a district hence reflect changes in capacity.

Panel B: Tests of significance of the differences in excess capacity across district groups, based on bootstrapped standard errors. From column 4

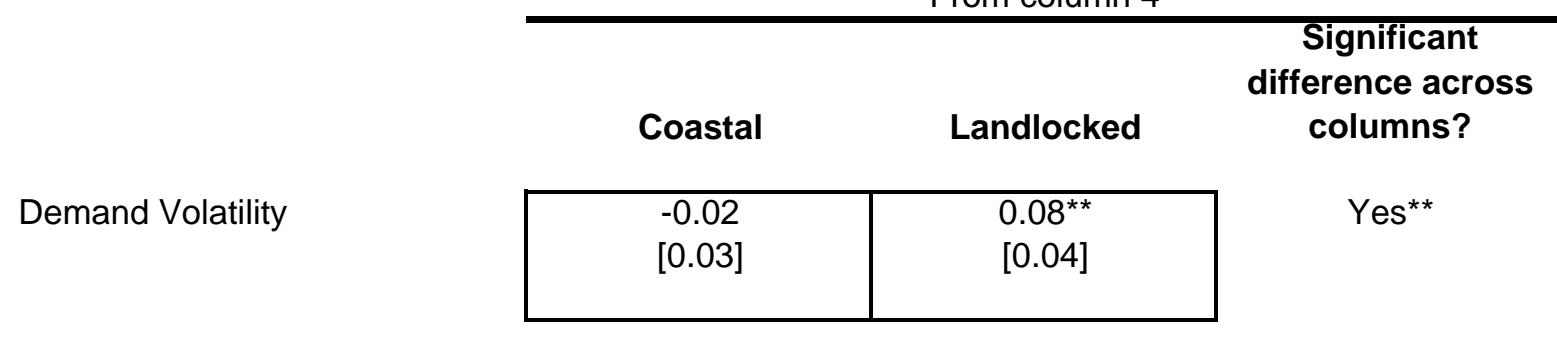


Table 9: Panel, Average Plant Size and Percentage Dry Process (Measures of Capacity Quality)

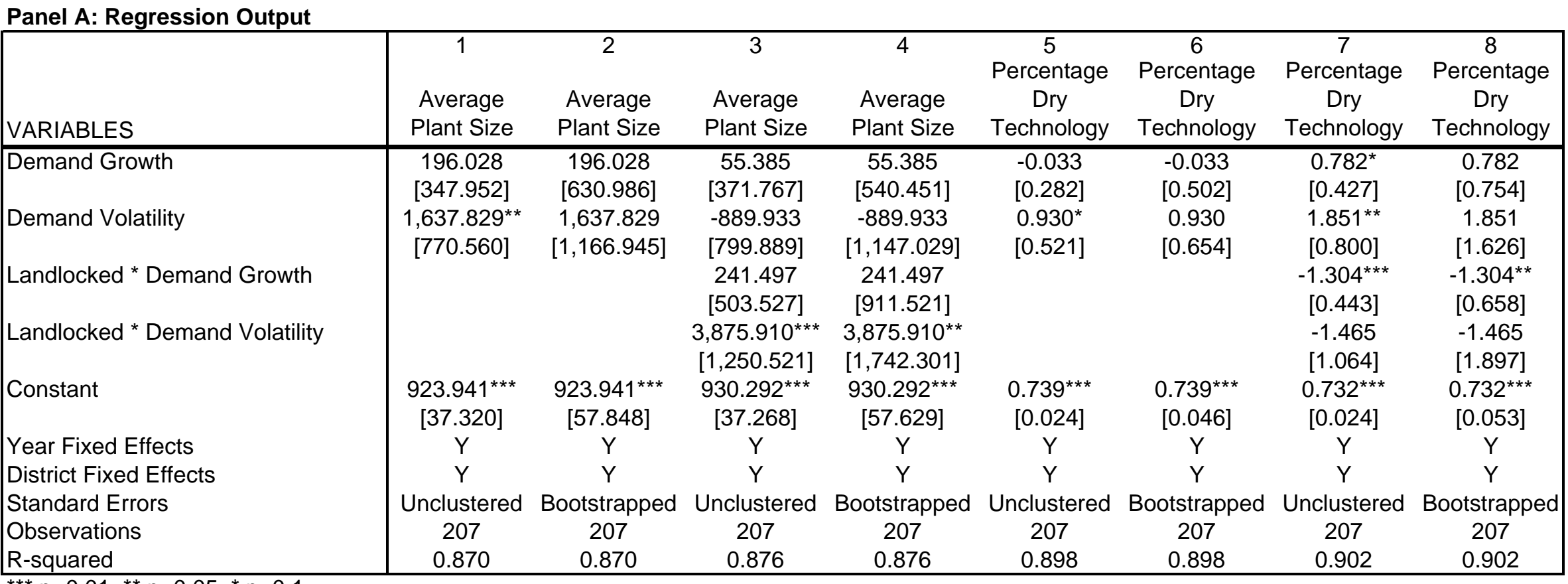

${ }^{\star \star \star} p<0.01,{ }^{* \star} p<0.05,{ }^{*} p<0.1$

Robust standard errors in brackets

Panel B: Tests of significance of the differences in capacity quality across district groups, based on bootstrapped standard errors.

\begin{tabular}{|c|c|c|}
\hline Coastal & Landlocked & $\begin{array}{c}\text { Significant } \\
\text { difference } \\
\text { across } \\
\text { columns? }\end{array}$ \\
\hline $\begin{array}{l}-25.80 \\
{[34.12]}\end{array}$ & $\begin{array}{c}86.55^{\star \star \star} \\
{[36.33]}\end{array}$ & Yes $^{\star *}$ \\
\hline
\end{tabular}

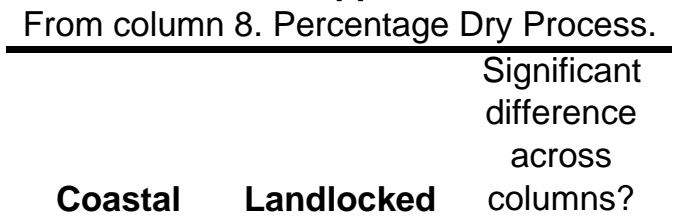

Demand Volatility
Yes**
No

\begin{tabular}{|c|c|}
\hline 0.05 & 0.1 \\
{$[0.05]$} & {$[0.2]$} \\
\hline
\end{tabular}

